\section{Profits of British science-based companies boom}

London. Underlining the potential links between science and wealth creation in a way that will warm hearts in the Cabinet Office, two British science-based companies last week reported significant increases in profits.

Amersham International, the health science group that grew out of the radioisotope supply service of the UK Atomic Energy Authority, announced that profits had increased by 27 per cent to $£ 26.3$ million in the financial year ending 31 March. And at Oxford Instruments, the advanced instrumentation group, profits have risen by 24 per cent to $£ 10.6$ million, thanks largely to the growing success of a joint venture set up with the German company Siemens to market nuclear magnetic resonance imaging (MRI) equipment for body scanning.

Amersham was one of the first government agencies to be privatized by the former Prime Minister Margaret Thatcher in the early 1980 s. It has since become the world's leading supplier of reagents for genome sequencing, boosted by its recent acquisition of US Biochemicals Corporation. Strong sales to medical and pharmaceutical research laboratories in both the United States and Britain resulted in an increase in turnover by its life sciences division from $£ 92.7$ million to $£ 98.9$ million.

The profits of this division nevertheless fell slightly, to $£ 19.1$ million, partly because of a flattening of sales in mainland Europe and Japan. But this fall in profits was also due to a 24 per cent increase of the division's spending on research and development, partly reflecting the company's efforts to develop new products for DNA sequencing. Later this year, for example, the company plans to launch what it calls a "laboratory robot" for purifying and sequencing DNA.

Like Amersham International, Oxford Instruments - a welcome turnaround after two successive years of declining profits has benefited from the fact that a large proportion of its sales are outside Britain, so that the company benefited from the devaluation of sterling last autumn.

Future prospects for Oxford Instruments will depend crucially on whether impending health reforms in the United States curb the potential market for body scanners. The company is also taking a chance on its ability to find a customer for a second synchrotron machine, designed to increase the density of circuits on microchips, which is under construction and will eventually be offered at a price of about $£ 16$ million ( $\$ 25$ million); the first such synchrotron built by the company is now being used almost exclusively by IBM.

David Dickson

\title{
Stanford seeks life after Cohen-Boyer patent expires
}

San Francisco. Stanford University in California is seeking a bridge across the gap in its finances that will be created when the Cohen-Boyer patent expires in 1997.

The patent, which covers insertion of foreign genetic material into bacterial plasmids, will by then have earned about $\$ 87$ million - an amount that has risen steadily each year since 1980 and which last year reached almost $\$ 15$ million. The royalties are shared with the University of California (UC) because Boyer is a professor of biochemistry and biophysics (now emeritus) at UC-San Francisco.

\section{Stanford's royal revenue producers}

\begin{tabular}{|c|c|c|}
\hline Exp & siration date & Amount \\
\hline Cohen/Boyer recombinant technology & 1997 & $\$ 14,660,699$ \\
\hline FM sounds & 1994 & $2,712,522$ \\
\hline $\begin{array}{l}\text { Fluorescent conjugates for } \\
\text { analysis of molecules and cells }\end{array}$ & 1992 & $2,023,125$ \\
\hline Computer X-Ray section scanner & 1994 & $1,079,579$ \\
\hline Stanford T-shirt logo & TM, no expiration & 245,926 \\
\hline Amplification of eucaryotic genes & 2004 & 289,043 \\
\hline Mouse anti-human hybridomas & not patented & 287,883 \\
\hline Anti-Leu-12 monoclonal antibody & not patented & 230,453 \\
\hline Pisces (software) & not patented & 227,415 \\
\hline $\begin{array}{l}\text { Antibody to the J-5 fragment } \\
\text { of bacterial endotoxin molecule }\end{array}$ & patent pending & 176,821 \\
\hline $\begin{array}{l}\text { Variable rate selective excitation } \\
\text { pulses for magnetic resonance imaging }\end{array}$ & $\begin{array}{l}\text { USA: } 2005 \\
\text { Europe: } 2008\end{array}$ & 171,000 \\
\hline Cell analysis system & expired 1991 & 157,331 \\
\hline $\begin{array}{l}\text { Method of treating autoimmune diseases } \\
\text { cell-mediated by Leu3 phenotype T cells }\end{array}$ & 2004 & 150,000 \\
\hline $\begin{array}{l}\text { Contour-clamped electric fields for } \\
\text { the separation of macromolecules }\end{array}$ & 2009 & 145,576 \\
\hline A new approach to digital reverberation & 2008 & 144,990 \\
\hline V-System (software) & not patented & 124,025 \\
\hline Asymmetric epoxidation process & 2003 & 111,779 \\
\hline NF-AT transcription system for screening & not patented & 111,000 \\
\hline
\end{tabular}
the immunosuppressive drugs the Fgl-5 cell line

Source: Office of Technoiogy Licensing. Stanford U., 1991-2

Stanford was for many years the most successful academic licensor to private industry in the United States, grossing \$25 million last year, although it now ranks second to the UC system. UC, which draws from a much larger research pool, is enjoying a burst of royalties from maturing patents and expects an additional boost in the mid-1990s from the activities of a recently expanded licensing group (see Nature 362, $395 ;$ 1993). The Cohen-Boyer patent is not even UC's largest revenue producer, having been eclipsed by a hepatitis vaccine and a nicotine patch.

But at Stanford, the biotechnology patent still reigns supreme (see table). The loss of income from it and several other lucrative patents will hit departments and faculty members hardest, as they share two-thirds of a patent's royalty income. David Botstein, chair of Stanford's department of genetics, says that the Cohen-Boyer money has helped to pay for new laboratories and renovations and to attract new faculty. But he compares the impact of the money to that of a legacy to a prudent working person: "they wouldn't make their lifestyle dependent on it".

Katharine $\mathrm{Ku}$, director of Stanford's Office of Technology Licensing says that research grants from the federal government, nonprofit organizations and industry provide much more money each year some $\$ 300$ million - and are a more reliable source of funding.

Nevertheless, Stanford hopes to make good the loss, following recommendations of an alumni task force, by taking equity rather than royalties from outside companies licensing inventions. Taking the title to all inventions involving the use of Stanford facilities or resources, including inventions funded by gift money, would also help.

The alumni also suggest that Stanford should clarify its policies on the work done by individual faculty members for outside partners, for fear that patenting policies may founder on conflicts of interest. The faculty has not yet reacted to that proposal, nor to the suggestion that Stanford should concentrate on technology with the highest potential return.

As a token of willingness to be more active on technology licensing, the university has transferred $\$ 2$ million to its Research Incentive Fund, which provides faculty with development seed money.

$\mathrm{Ku}$, whose office operates on money from a 15 per cent share of licensing revenues, is hopeful about inventions for sound synthesis for multimedia products, as well as about a fundamental technology for atomic resolution instruments and memory systems. His personal choice is nanotechnology.

In any event, Stanford has learned that patents are a long-term and difficult source of funding. Nevertheless, after subtracting payments to other universities, Stanford last year received \$18.5 million. Sally Lehrman 